\title{
The Principle of Non-discrimination: An Empty Promise for the Preventive Health Care of Asylum Seekers and Undocumented Migrants?
}

Veronika Flegar*

DOI: $10.21827 / 5 a 86 a 8 e d a 4 e d 2$

\author{
Keywords \\ Preventive Health Care; Asylum Seeker; Undocumented Migrant; Right to \\ Health; General Comment 14; Non-Discrimination; General COMMENT 20
}

\begin{abstract}
The principle of non-discrimination in Article 2 of the International Covenant on Economic, Social and Cultural Rights (ICESCR) holds that its rights are equally applicable to 'everyone'. Nevertheless, evidence from the national context suggests that access to health care for asylum seekers and undocumented migrants depends on their legal status and in particular, preventive health care is often inaccessible to them. ${ }^{1}$ This has led to several hitherto under-investigated questions concerning the right to health in this context: Does a right to preventive health care exist at the international level? If so, what individual rights and State obligations are involved in this right? How does the principle of non-discrimination relate to this right? Does this principle offer (additional) protection to asylum seekers and undocumented migrants in terms of a possible right to preventive health care? Method: The main issue is what the principle of nondiscrimination has to offer for the preventive health care of persons without a regular residence status. Based on an analysis of the non-binding, but authoritative, General Comments of the United Nations (UN) Committee on Economic, Social and Cultural Rights (CESCR), the paper takes an exploratory style that goes beyond traditional legal analysis and investigates how the law should be interpreted in order to enhance its effectiveness and relevance. Results and Discussion: Strictly speaking, there is no explicit, binding right to preventive health care for asylum seekers or undocumented migrants in the ICESCR itself. ${ }^{2}$ Nevertheless, implications can be found in the CESCR General Comments Number 14 and $20 .{ }^{3}$ Particularly, if one takes into account how the law
\end{abstract}

* Veronika Flegar, LLM is a PhD Candidate at the Faculty of Law, University of Groningen, the Netherlands. E-mail: vflegar@hotmail.com.

1 See, for instance, Centre on Migration Policy and Society (COMPAS), Spencer, S and Hughes, V, REPORT: Outside and In: Legal Entitlements to Health Care and Education for Migrants with Irregular Status in Europe, University of Oxford, July 2015, at <compas.ox.ac.uk/research/welfare/service-provisionto-irregular-migrants-in-europe/> (accessed 1 October 2015).

2 UN General Assembly, International Covenant on Economic, Social and Cultural Rights (1966) 993 UNTS 3 (ICESCR).

3 Committee on Economic Social and Cultural Rights (CESCR), General Comment 14: The Right to the Highest Attainable Standard of Health, UN Document E/C.12/2000/4, 11 August 2000 (GC 14); and CESCR, General Comment 20: Non-Discrimination in Economic, Social and Cultural Rights, UN Document E/C.12/GC/20, 2 July 2009 (GC 20). 
should be interpreted according to CESCR General Comment 14 (CESCR GC 14), there should be a right to preventive health care for asylum seekers and undocumented migrants. The exact content of such a right, however, is less clearly defined. Further, the principle of non-discrimination is not conclusive as to whether the right to health would apply equally to asylum seekers and/or undocumented migrants as it would to nationals. Conclusion: For non-discrimination to be truly unambiguous with regard to the preventive health care of asylum seekers and undocumented migrants, it would be necessary to strike out the 'general welfare' provision of CESCR General Comment 20 (CESCR GC 20) and to clearly state that the 'other status' criterion also entails 'residence status'. In that sense, the principle of non-discrimination is, indeed, an empty promise and the right to preventive health care for asylum seekers and undocumented migrants seems to be much better protected under the CESCR GC 14's non-discriminatory interpretation of the right to health itself.

\section{Introduction}

Differences in access to health care are especially discomforting when it comes to persons in situations of vulnerability. This is also the case with regard to individuals who have had to leave their home country involuntarily (asylum seekers) or who find themselves in an irregular situation (undocumented migrants). ${ }^{4}$ It is apparent that a substantial amount of internationally relocated persons are asylum seekers or individuals without a residence status. In 2014, 1.7 million asylum seekers were recorded worldwide. ${ }^{5}$ Numbers on undocumented persons are a lot harder to acquire due to the very nature of their undocumented status. Estimates on undocumented persons worldwide figure around 10$15 \%$ of the 214 million international migrants $(2010) .{ }^{6}$ Asylum seekers are not residing in the host country irregularly for the duration of their asylum procedure and are entitled to more explicit rights during their stay. ${ }^{7}$ On the contrary, the residence status and rights of undocumented persons are much less clearly defined, which usually leaves them in a more precarious situation. ${ }^{8}$

4 For the purpose of this paper, 'leaving their home country involuntarily' is considered to refer to persons applying for asylum on the grounds of Article 1(A)2 of the Convention Relating to the Status of Refugees or applying for subsidiary protection in accordance with the (regionally) applicable subsidiary protection regime. Persons in an irregular situation or 'undocumented migrants', refers to individuals outside their country of nationality who are not in transit but reside in another country without a legally valid residence permit. People can have become irregular for various reasons such as having entered the country illegally, being born in the country to undocumented parents, having overstayed a visa, being a rejected asylum seeker or having lost a previous regular or asylum residence permit.

5 UN High Commissioner for Refugees (UNHCR), REPORT: UNHCR Global Trends: Forced Displacement in 2014, 18 June 2015, at <unhcr.org/556725e69.html> (accessed 1 October 2015), 3.

6 International Organization for Migration (IOM), World Migration Report 2010, 2010, at <publications.iom.int/bookstore/free/WMR_2010_ENGLISH.pdf> (accessed 1 October 2015), 29.

7 Regional examples include the EU Reception Conditions Directive, which lays down the rights of asylum seekers while their asylum request is pending. Directive 2013/33/EU of the European Parliament and of the Council of 26 June 2013 lays down standards for the reception of applicants for international protection, OJ L180/96.

8 See, for instance, Biswas, D, Toebes, B and Hjern, A et al., "Access to Health Care for Undocumented Migrants from a Health Perspective: A Comparative Study of Denmark, Sweden, and the Netherlands" 14(2) Health and Human Rights (2012) 49. 
Being located outside of their country of origin makes asylum seekers and undocumented migrants particularly vulnerable to harm. ${ }^{9}$ This can be due to the experiences in their home country, during the flight or upon arrival in the host country. ${ }^{10}$ According to Suurmond, asylum seekers have 'unique and complex health needs' of which 'inadequate vaccinations, nutritional deficiencies and infectious diseases' are only a few examples. ${ }^{11}$ Additional problems may arise due to 'physical and mental health problems, language and cultural barriers, unfamiliarity with the healthcare system and limited health literacy'. ${ }^{12}$ Dang points out that asylum-seeking children in particular face 'an increased risk for many infectious diseases' due to traumatic experiences, malnutrition and inadequate previous health care. ${ }^{13}$ Although the situation of undocumented migrants is much harder to assess due to their irregular status, it can be assumed that most of the above assertions regarding health care hold equally true for them as they often find themselves in an even more difficult situation than asylum seekers. ${ }^{14}$

Considering that the preamble of the Universal Declaration of Human Rights (UDHR) refers to the 'equal and inalienable rights of all members of the human family', one would assume that the rights of all persons are equally protected by international human rights law. ${ }^{15}$ Similarly, the non-discrimination clauses built into most international human rights treaties, combined with the extra non-discrimination clauses included in some substantive rights, suggest extra protection to those most susceptible to discrimination and unequal treatment. ${ }^{16}$ However, examples from the national context in the field of health care sketch a less positive picture. ${ }^{17}$

Not only is limited or inadequate health care a problem in itself, but the limiting of health services may also restrict the possibility to enjoy other rights. CESCR GC 14 on the right to health recognizes that '[h]ealth is a fundamental human right indispensable for the exercise of other human rights'. ${ }^{18}$ Yet, many countries only provide emergency care to

9 See, for instance, Pitkin Derose, K, Escarce, J, and Lurie, N, "Immigrants And Health Care: Sources of Vulnerability" 26(5) Health Affairs (2007) 1258-.

10 Zwi, K and Mares, S, "Commentary: Reducing further Harm to Asylum-seeking Children. The Global Human Rights Context" 43(1) International Journal of Epidemiology (2013), 105.

11 Suurmond, J, Rupp, I and Seeleman, C et al., "The first contacts between healthcare providers and newly-arrived asylum seekers: a qualitative study about which issues need to be addressed" 127(7) Public Health (2013), 668.

$12 \quad I d, 668-669$.

13 Dang, K and Tribble, A, "Strategies in Infectious Disease Prevention and Management Among USBound Refugee Children" 44(7) Current Problems in Pediatric and Adolescent Health Care (2014), 196.

14 See, for instance, the recent discussion in the Netherlands about whether undocumented migrants should enjoy basic rights. The discussion was sparked by the European Committee of Social Rights' (ECSR) decision in Conference of European Churches (CEC) v the Netherlands Complaint No. 90/2013, 10 November 2014.

15 Preamble, UN General Assembly, Universal Declaration of Human Rights (1948) 217 A (III) (UDHR).

16 In addition to Article 2 ICESCR, a separate non-discrimination article can be found in Article 1, UN General Assembly, International Convention on the Elimination of All Forms of Racial Discrimination (1965) 660 UNTS 195 (CERD); Article 2, UN General Assembly, International Covenant on Civil and Political Rights (1966) 999 UNTS 171 (ICCPR); Article 1, UN General Assembly, Convention on the Elimination of All Forms of Discrimination Against Women (1979) 1249 UNTS 13 (CEDAW); Article 2, UN General Assembly, Convention on the Rights of the Child (1989) 1577 UNTS 3 (CRC); Article 1, UN General Assembly, International Convention on the Protection of the Rights of All Migrant Workers and Members of their Families (1990) 2220 UNTS 3; UN General Assembly, Convention on the Rights of Persons with Disabilities (2006) 2515 UNTS 3.

17 Spencer and Hughes, supra nt 1.

18 CESCR GC 14, supra nt 3, para 1. 
'non-citizens' ${ }^{19}$ Other aspects of primary care, especially preventive care, receive much less attention. ${ }^{20}$ Even in countries with universal healthcare coverage, asylum seekers and undocumented migrants receive less preventive health care than nationals. ${ }^{21}$ In addition, even if States allow for broader access to health care for non-nationals, many practical barriers remain. ${ }^{22}$ This is especially problematic as the abovementioned additional health risks and needs of asylum seekers and undocumented migrants would suggest the necessity of increased, rather than limited, care compared to nationals.

Rose et al. argue that '[t]he primary determinants of disease are mainly economic and social' which implies that asylum seekers and undocumented migrants, who usually find themselves in a weak social and economic position, are more likely to become ill. ${ }^{23}$ In order to avoid this, Rose et al. claim that social and economic measures must be taken, of which preventive measures should constitute an essential component. ${ }^{24}$ However, preventive health care is often neglected and not considered as an aspect of health care requiring separate attention. Discussing preventive health care as a separate issue and not only in the trinity of preventive, curative and palliative health care, is innovative and extremely necessary to increase its visibility and highlight its relevance. It goes beyond the scope of this analysis to discuss the medical necessities, usefulness and content of preventive health care in more detail. Rather, this normative study investigates what the right to preventive health care should look like according to CESCR GC 14 on the right to health and whether this should also be applicable to asylum seekers and undocumented migrants in accordance with CESCR GC 20 on the principle of nondiscrimination.

The present analysis does not provide an all-encompassing view of the legal situation and does not focus on the content of the principle of non-discrimination or of the right to health in more general terms, which has been discussed extensively elsewhere. ${ }^{25}$ Rather, the study refers to preventive health care and non-discrimination in the context of asylum seekers and undocumented migrants to provide a starting point for further discussion on the existence, content and effectiveness of these concepts. This approach is chosen in order to contribute to the visibility of these concepts and to ensure increased clarity on State obligations and individual rights in this regard. Eventually, this might lead to a

19 UN Office of the High Commissioner for Human Rights (OHCHR), Fact Sheet No. 31: The Right to Health, June 2008, at <http://www.refworld.org/docid/48625a742.html> (accessed 13 August 2015), 19.

20 Compare Spencer and Hughes, supra nt 1. See also De Nationale Ombudsman, van der Bij1, N et al., REPORT: Medische Zorg voor Vreemdelingen - Over toegang en continuiteit van medische zorg voor asielzoekers en uitgeprocedeerde asielzoekers, Report Number 2013/125, 3 October 2013, at $<$ nationaleombudsman.nl/uploads/2013-

125_rapport_medische_zorg_vreemdelingen_webversie_0.pdf $>$ (accessed 1 October 2015).

21 Martin, Y, Collet, T and Bodenmann, P et al., "The Lower Quality of Preventive Care among Forced Migrants in a Country with Universal Healthcare Coverage" 59 Preventive Medicine (2014), 19.

22 Such barriers can potentially be identified at the 'patient level', the 'provider level' and the 'system level'. Scheppers, E, van Dongen, E and Dekker, J et al., "Potential Barriers to the Use of Health Services among Ethnic Minorities: a Review" 23(3) Family Practice (2006) 325.

23 Rose, G, Khaw, K and Marmot, M, Rose's Strategy of Preventive Medicine (2nd ed, Oxford University Press, New York, 2008), 162.

$24 \quad$ Ibid.

25 See, for instance, on the right to health Toebes, B, The Right to Health as a Human Right in International Law (Intersentia, Antwerp, 1999) and on the principle of non-discrimination Vandenhole, W, Nondiscrimination and Equality in the View of the UN Human Rights Treaty Bodies (Intersentia, Antwerp, 2005). 
better application and realisation of the right to health for asylum seekers, undocumented migrants and all other persons in a vulnerable situation. ${ }^{26}$

To enhance the clarity of this study and promote the focus on widely recognised and authoritative international documents, the analysis refrains from reference to regional or national legal documents and international human rights treaties other than the ICESCR. Through outlining the ICESCR's legal framework with regard to preventive health care, this paper nevertheless tries to provide a starting point for further discussion on regional and national policies, practices of preventive health care in general, and, particularly, asylum seekers and undocumented migrants.

Against this background, the research investigates the following two questions: What individual rights and State obligations are involved in the right to preventive health care? Does the principle of non-discrimination offer (additional) protection to asylum seekers and undocumented migrants in terms of the right to preventive health care?

\section{Method}

This normative study is innovative in that it takes a forward-looking human rights-based approach that calls for a full implementation of the right to health beyond any State interest limitations. The general method of interpretation used for the documents under investigation is the doctrinal legal method, which attempts to systematise and generalise the law in order to find inconsistencies and gaps in the existing framework. ${ }^{27}$ Based on this, the article takes an exploratory style that goes beyond traditional legal analysis and investigates how the law should be formulated and interpreted based on the soft law of the CESCR General Comments in order to enhance its effectiveness and relevance. The goal of this analysis is to highlight some of the identified inconsistencies and possibilities but the study does not have the ambition to be all-encompassing in that respect.

The principle of non-discrimination was identified as a potentially valuable concept for clarifying individual rights and State obligations for the preventive health care of asylum seekers and undocumented migrants. This is due to the fact that it commonly suggests equality of treatment and could therefore provide insights on the legality of differential treatment of these persons compared to nationals. Consequently, the desk research conducted in July 2015 embarked upon the identification of the relevant binding and non-binding documents on the right to health and non-discrimination at the international level. This was accomplished through a review of academic literature related to the search terms 'preventive health care', 'health + migration', 'health + undocumented migrants', 'health + asylum seekers', and 'the right to health'. In addition, the websites of relevant international institutions and organizations, namely the CESCR, the UN Committee on the Rights of the Child (UNCRC), the World Health Organization (WHO), the International Organization for Migration (IOM), the UN High Commissioner for Refugees (UNHCR), the UN Children's Fund (UNICEF), and the

26 The paper uses the term 'right to health' as an abbreviation for the 'right to the highest attainable standard of physical and mental health' as mentioned in Article 12 ICESCR. While it is apparent that the right entails much more than only a right to health care, the present study neglects these other aspects in order to highlight the importance of the right to preventive care.

27 Compare with Hutchinson, T, "Doctrinal Research: Researching the Jury" in Watkins, D and Burton, M, eds, Research Methods in Law (Routledge, London, 2013). 
UN High Commissioner for Human Rights (UNHCHR), were searched for documents on the basis of similar search terms.

Subsequently, a qualitative content analysis was conducted in which the relevant binding treaties and related General Comments were identified and scanned for reference to non-discrimination, preventive health, migration, and asylum. On this basis, the documents were sorted according to their relevance for the case of asylum seekers and undocumented migrants. While other specific UN treaties, such as the UN Convention on the Rights of the Child (CRC), the International Convention on the Protection of the Rights of All Migrant Workers and their Families (ICPMW), and the International Convention on the Elimination of All Forms of Racial Discrimination (ICERD) were considered relevant for background knowledge, the decision was made to focus exclusively on the ICESCR as the most relevant, authoritative and generally applicable international legal framework which contains both the right to health and the principle of non-discrimination. ${ }^{28}$

Based on this preliminary inquiry, suggestions were articulated as to how international human rights law should be formulated and interpreted if a non-discriminatory approach to preventive health care for asylum seekers and undocumented migrants is to be followed. These suggestions are outlined in the results section below.

\section{Results and Discussion}

Due to the abovementioned findings regarding the relevant documents, the results section of this paper focuses on the ICESCR and the relevant General Comments of its treaty body, the CESCR. The results are divided into two parts: Part I outlines the scope and content of the right to preventive health care in general. Part II examines the scope and content of the non-discrimination principle in light of preventive health care with regard to asylum seekers and undocumented migrants.

\section{III.1. The Right to Preventive Health Care}

As it is necessary to first clarify the substantive provision in order to point out possible starting points for the principle of non-discrimination, the first part of the results section outlines the scope and content of the right to preventive health care in general. It tries to answer the following question: Which individual rights and State obligations are involved in the right to preventive health care? First, the study sketches what preventive health care can entail from a medical perspective before considering the most relevant article, Article 12 ICESCR on the highest attainable standard of physical and mental health, and the respective considerations in CESCR GC 14 as to how the article should be interpreted.

The study does not engage in any debate on the cost-effectiveness or medical usefulness of preventive health care in general or of specific preventive health care measures, unless the legal documents scrutinised explicitly refer to such issues. Rather, it

28 With currently 164 ratifications, the ICESCR is the most widely recognised general instrument on the right to health. UN Treaty Collection, International Covenant on Economic, Social and Cultural Rights, 1 October 2015, at <treaties.un.org/Pages/ViewDetails.aspx?src=TREATY\&mtdsg_no=IV$3 \&$ chapter $=4 \&$ lang $=\mathrm{en}>$ (accessed 1 October 2015$)$. 
assumes that for especially susceptible persons, such as asylum seekers or undocumented migrants, preventive measures are indispensable. ${ }^{29}$

Although the analysis focuses on the legal sphere, it contributes to a better contextual understanding of the medical perspective in that respect. Previous research on preventive health care seems to have primarily focused on related issues from a public health perspective rather than from an individual rights perspective. In a similar context, Patterson and Chambers define preventive health care as being either

primary (lifestyle counselling and immunizations), secondary (early detection of subclinical disease by screening or case finding to prevent disability), or tertiary (minimising disability and handicap from established disease).$^{30}$

A perspective on the individual benefits of preventive medicine can be found in several medical encyclopaedias. As such, the medical encyclopaedia of the US National Library of Medicine suggests that preventive health care has the purpose to

[s]creen for diseases, such as high blood pressure or diabetes; [1]ook for future disease risks, such as high cholesterol and obesity; [d]iscuss alcohol use and safe drinking and tips on how to quit smoking; [e]ncourage a healthy lifestyle, such as healthy eating and exercise; [u]pdate vaccinations; [m]aintain a relationship with [a] health care provider in case of illness. ${ }^{31}$

The medical encyclopedia of the University of Rochester provides detailed suggestions of prevention measures to be taken depending on age and gender. ${ }^{32}$ It goes beyond the scope of this paper to go into detail on the advised measures. Nevertheless, one should keep in mind that preventive health care has to be tailored to the needs of the specific individual, depending on factors such as age and gender but also depending on other individual risk factors such as the socio-economic situation or the (family's) medical history. Unfortunately, no academic literature discussing such tailored preventive measures for asylum seekers or undocumented migrants seem to exist, yet. ${ }^{33}$

Moving from academic research and recommendations by medical experts to the policy area, the US-American 'Obamacare package' offers an example of what concrete measures preventive health care can entail in practice: the package includes a list of 18

29 See above section 'Background'.

30 Patterson, C, and Chambers, LW, "Preventive Health Care", 345 The Lancet (1995) 1611.

31 Some of the measures could include (but the list is by no means exhaustive): 'Blood pressure, Blood sugar, Cholesterol (blood), Colon cancer screening test, Depression screening, Genetic testing for breast cancer or ovarian cancer in certain women, HIV test, mammogram, Osteoporosis screening, Pap smear, Tests for Chlamydia, gonorrhea, syphilis, and other sexually transmitted diseases'. MedlinePlus, 'Preventive Health Care', U.S. National Library of Medicine, 22 January 2013, at <nlm.nih.gov/medlineplus/ency/article/001921.htm> (accessed 11 November 2015).

32 University of Rochester Medical Center, Health Encyclopedia, 2015, at <urmc.rochester.edu/encyclopedia/SearchResults.aspx?queryText=prevention\&xsltPath=/encyclope $\mathrm{dia} /$ EncyclopediaResults.xslt\&searchIn=encyclopedia\&start=0 $>$ (accessed 11 November 2015).

33 Feldman provides a valuable starting point in discussing the primary health care of asylum seekers. However, a special focus on preventive health care and a similar discussion of undocumented migrants could be a valuable addition of future research. Feldman, R, "Primary Health Care for Refugees and Asylum Seekers: A Review of the Literature and a Framework for Services", 120 Public Health (2006) 809-816. 
'preventive health services for adults', all of which are offered free of charge. ${ }^{34}$ The following highlights whether the international level attaches similar importance to preventive health care and if so, in what way. In so doing, the section outlines preventive health care in the ICESCR.

Although not legally binding, WHO Fact Sheet 31 not only recognises preventive health care as part of primary health care or as one of many aspects of the right to health that should be taken into account, but rather clearly names a 'right to prevention'. ${ }^{35}$ However, the ICESCR and its General Comments are less outspoken on this matter.

According to Article 12(1) ICESCR, everyone is entitled 'to the enjoyment of the highest attainable standard of physical and mental health.' Article 12(2) ICESCR further specifies that provisions necessary for the prevention 'of epidemic, endemic, occupational and other diseases' should be included in the steps that States take towards the right's implementation. This means that there is an actual, binding legal basis for the right to preventive health care in the ICESCR. However, the interpretation thereof is left to soft law instruments, of which CESCR GC 14 is the most important one.

The right to preventive health care is more explicitly stated in the CESCR GC 14 which holds that Article 12(2) 'requires the establishment of prevention and education programmes for behavior-related health concerns [...] and the promotion of social determinants of good health' ${ }^{36}$ Moreover, CESCR GC 14 recognises that a large variety of social and economic aspects is involved in keeping people healthy. ${ }^{37}$ Based on this reasoning, the CESCR assumes that the right to health also entails 'underlying determinants of health' which include the availability of information and education on health, one important aspect of preventive health care. ${ }^{38}$

CESCR GC 14 also recognises that the right to health involves the right to a broad range of 'facilities, goods, services and conditions' which are essential for realising 'the highest attainable standard of health'. ${ }^{39}$ This also extends to 'the provision of equal and timely access to basic preventive [...] services and health education, [and] regular screening programmes'. ${ }^{40}$ An important addition is made through the statement that States should not disproportionately invest in the provision of curative health care, which is very expensive and can often only be accessed by the more privileged layers of society, while preventive health care is beneficial to a much larger proportion of society. ${ }^{41}$ This emphasises the importance of preventive health care especially to the more vulnerable parts of the population - such as asylum seekers and undocumented migrants. However, CESCR GC 14 does not state what exactly preventive health care should entail or how far it should stretch.

With regard to the State obligations entailed in the right to health, CESCR GC 14 clearly states that preventive health care forms part of primary health care and is therefore a core obligation of the right to health. ${ }^{42}$ This core obligation includes the requirement to maintain immunisation programmes, to prevent diseases and to educate

34

35

36

37

38

39

$40 \quad I d$, para 17

$41 \quad$ Id, para 19.

42 Id, paras $44(\mathrm{~b}),(\mathrm{c}),(\mathrm{d})$.

OHCHR, supra nt 19, 3.

$I d$, para 4 .

$I d$, paras 4 and 11 .

Id, para 9.

Healthcare.gov, 'Preventive Health Services for Adults', U.S. Centers for Medicare \& Medicaid Services, 2015, at <healthcare.gov/preventive-care-benefits/adults/> (accessed on 11 November 2015).

CESCR, GC 14, supra nt 3, para 16. 
and inform the population about health challenges and prevention possibilities. ${ }^{43}$ With regard to the obligation to fulfil, CESCR GC 14 not only recurrently mentions that States have to provide immunisation, but also that States have to make sure that the 'underlying determinants of health' are equally accessible to all. ${ }^{44}$

The analysis suggests that Article 12 ICESCR should entail a right to preventive health care, that there exists a binding legal basis for such a right and that, as part of primary health care, it should be considered a core obligation of the right to health. It is clear from CESCR GC 14 that preventive health care includes measures such as immunisation, education and attention to the underlying determinants of health. However, the exact measures to be taken remain unspecified.

Nevertheless, based on the analysis of CESCR GC 14, one can conclude that preventive health care as a human right can be summarized to encompass the prevention of epidemic, endemic, occupational and other diseases. Measures should at least include:

- Immunisation

- Education and information on health and behavior-related health concerns

- Regular screening programmes

- Promotion of the social determinants of health.

Overall, this shows that States have much leeway in complying with the right to preventive health care and it seems hard to discover a violation if the criteria are so broadly defined. Nevertheless, these criteria provide a valuable starting point which emphasises that preventive health care forms an integral part of the right to health. Based on this starting point, it is possible to further outline whether the non-discrimination principle can contribute towards clarifying preventive health care of asylum seekers and undocumented migrants.

\section{III.2. The Principle of Non-discrimination}

The second part of this section focuses on the question of whether the principle of nondiscrimination offers (additional) protection to asylum seekers and undocumented migrants in terms of the right to preventive health care. The analysis does not discuss the content of the principle of non-discrimination in more general terms. ${ }^{45}$ Rather, the following focuses on three largely intertwined aspects of the principle of nondiscrimination that are relevant for detecting any links with the preventive health care of asylum seekers and undocumented migrants: 1 . the reach of the material scope of nondiscrimination with regard to preventive health care; 2 . the extent of the personal scope of non-discrimination in terms of residence status; and 3 . the reference to nondiscrimination in the right to health itself.

According to Abramson, the principle of non-discrimination can be seen as one of the 'umbrella right[s]' of international law which increases the protection of the 'sectoral rights' ${ }^{46}$ As such, non-discrimination usually receives attention in relation to another human right, which is why the following analysis of the principle in relation to the right

43 Ibid.

$44 \quad$ CESCR, GC 14, supra nt 3, para 36.

45 On the principle of non-discrimination in more general terms see, for instance, Vandenhole, supra nt 25.

46 Abramson, B, "Article 2: The Right to Non-Discrimination" in Alen, A, Vande Lanotte, J, Verhellen, E, Ang, F, Berghmans, E and Verheyde, M, eds, A Commentary on the Convention on the Rights of the Child, (Martinus Nijhoff Publishers, Leiden, 2008), 7. 
to preventive health care is well suited. With regard to the question whether the material scope of the principle of non-discrimination stretches to the right to health in general, the answer seems thus quite clear. Also the right to health of Article 12 ICESCR 'recognize[s] the right of everyone to the enjoyment of the highest attainable standard of physical and mental health'. ${ }^{47}$ However, the article does not explicitly refer to any specific criteria on the basis of which any particular person should not be excluded. While one would easily assume that 'everyone' really includes every human being, which would make any relation to non-discrimination in Article 2(2) ICESCR irrelevant, examples from practice show that States do not necessarily agree - especially when it comes to persons with a temporary or no residence status. ${ }^{48}$ What is more, judging from this article it is not explicit whether non-discrimination equally applies to preventive health care. In order to clarify this issue, the following tries to reveal how the criteria of non-discrimination relate to the right to preventive health care and whether 'everyone' also includes asylum seekers and undocumented migrants.

In addition to reference to 'equal and inalienable rights' in the preamble of the UDHR, the principle of non-discrimination is laid down in Article 2 UDHR which asserts that all human beings are entitled to

'all the rights and freedoms [...] without distinction of any kind, such as race, colour, sex, language, religion, political or other opinion, national or social origin, property, birth or other status'.

The term 'all the rights' suggests that no differentiation or hierarchy of rights should be introduced but that everyone is entitled to enjoy the same, full and unlimited rights international human rights law has to offer. Based on this article, most of the subsequent international human rights treaties have adopted a similar provision. ${ }^{49}$ Due to the more concrete relationship with the right to health, the following again focuses on the ICESCR as the most relevant framework in that respect.

Article 2(2) ICESCR holds that

[t] he States Parties to the present Covenant undertake to guarantee that the rights enunciated in the present Covenant will be exercised without discrimination of any kind as to race, colour, sex, language, religion, political or other opinion, national or social origin, property, birth or other status.

Since no specific mention is made of any right that is included or excluded from the principle completely or to a certain degree, it is apparent from the article that the prohibition equally applies to all rights of the ICESCR, regardless of any additional mentioning of non-discrimination in the article on the substantive right. Hence, the principle of non-discrimination should apply equally to all aspects of the right to health, including preventive health care.

CESCR GC 20 on the principle of non-discrimination equally suggests that Article 2(2) ICESCR should be read as applying to the right to health and entailing that 'States parties have immediate obligations in relation to the right to health, such as the guarantee

$47 \quad$ Emphasis added.

48 See, for instance, Spencer and Hughes, supra nt 1.

49 See CESCR, supra nt 16. 
that the right will be exercised without discrimination of any kind' ${ }^{50}$ Non-discrimination is seen as 'an immediate and cross-cutting obligation' and consists of

any distinction, exclusion, restriction or preference or other differential treatment that is directly or indirectly based on the prohibited grounds of discrimination and which has the intention or effect of nullifying or impairing the recognition, enjoyment or exercise, on an equal footing, of Covenant rights. ${ }^{51}$

While this once more suggests that non-discrimination is very inclusive, no explicit link to preventive health care is made. No further explanation is offered with regard to what the right to health entails or what exactly falls within the scope of non-discrimination. Nevertheless, as outlined above, CESCR GC 14 indicates that the right to preventive health care should be seen as a clear core obligation of the right to health. This suggests that even if it is not explicitly referred to in the context of non-discrimination, it should be seen as equally falling within its scope as part of the right to health which is clearly linked to non-discrimination. This is supported by the emphasis on inclusivity of the principle of non-discrimination.

The question of whether the personal scope of the article also extends to asylum seekers and undocumented migrants is less clear: the list of prohibited grounds for discrimination does not explicitly refer to residence status or to a similar category that would imply their inclusion and the article does not explicitly mention that the list of prohibited grounds can be expanded any further. However, Article 2(3) ICESCR allows developing countries to limit access to the economic rights of the ICESCR for nonnationals. Although not explicitly stated, this suggests that no such limitation is allowed for developed countries. ${ }^{52}$ It is also important to note that no exclusion clause for foreigners as in, for instance, the Appendix of the European Social Charter, exists with regard to the ICESCR. ${ }^{53}$

Regarding the prohibited grounds of discrimination, important differences in Article 2(2) ICESCR as compared to the Article 2 UDHR should be noted: the most apparent difference is the reference to 'distinction' in the UDHR whereas the ICESCR refers to 'discrimination'. One might assume that 'discrimination' is a stronger term which necessitates a higher standard of proof than 'distinction'. However, Abramson argues that in practice both terms are used interchangeably. ${ }^{54}$ The present analysis does therefore not go into more detail on this issue as it is not directly relevant to the question under investigation. Yet, this is not the only difference between the two Articles. Another discernible difference is that the UDHR mentions distinction 'such as', whereas the ICESCR refers to discrimination 'as to'. This suggests that while the former sees discrimination on the basis of the explicitly mentioned prohibited grounds only as

50 CESCR, GC 14, supra nt 3, para 30.

51 CESCR, GC 20, supra nt 3, para 7.

52 While the present study does not explicitly refer to a particular country, the rights and State obligations for asylum seekers and undocumented migrants it tries to uncover are primarily directed at developed countries (ie those with a functioning health care system) as developing countries display different problems and access to health care might not even be ensured for nationals.

53 Although refuted by later case law, the European Social Charter holds that foreigners are only included 'in so far as they are nationals of other Parties lawfully resident or working regularly within the territory of the Party concerned': Appendix 1, Council of Europe, European Social Charter (revised) (1996) ETS 163.

54 Abramson, supra nt 46, 8. 
examples and considers all forms of distinction to be prohibited, the latter is much more limited and the term 'as to' refers to a much more exclusive list of the prohibited grounds of discrimination. Nevertheless, both documents include the term 'other status', which the following presents as indicating some possible leeway for interpretation.

While the term 'other status' could have been considered to entail a prohibition of discrimination on the grounds of residence status, this is not explicitly mentioned. Nevertheless, the CESCR sees the prohibited grounds of discrimination as expandable. Accordingly, CESCR GC 20 holds that the term 'other status' suggests an incomplete list of prohibited grounds of discrimination and even states that this list 'is not intended to be exhaustive'. ${ }^{55}$ The CESCR's interpretation is based on the argument that ' $\left.\mathrm{t}\right]$ he nature of discrimination varies according to context and evolves over time', which necessitates a more 'flexible approach'. ${ }^{56}$ Hence, the criteria for discrimination should 'reflect the experience of social groups that are vulnerable and have suffered and continue to suffer marginalization' ${ }^{57}$ Judging from this argumentation it is not surprising that CESCR GC 20 suggests that the term 'everyone' should include 'non-nationals, such as refugees, asylum seekers, stateless persons, migrant workers and victims of international trafficking, regardless of legal status and documentation'. ${ }^{58}$

In addition, it is not difficult to imagine that the, in CESCR GC 20 under the 'other status' criterion mentioned, prohibited grounds of discrimination 'place of residence' and 'economic and social situation' can also be considered to entail possible grounds that prohibit any form of discrimination against asylum seekers and undocumented migrants. ${ }^{59}$ Within the additional categories which the CESCR considers to be implied by the 'other status' ground, CESCR GC 20 also makes the remarkable addition of 'nationality'. ${ }^{60}$ This seems confusing, as 'national origin' is already entailed as an explicit separate category in Article 2(2) ICESCR. The 'national origin' ground does not mention asylum seekers or undocumented migrants and rather states that it 'refers to a person's State, nation, or place of origin'. ${ }^{61}$ Nevertheless, one can easily conclude that in particular circumstances - namely if discrimination really takes place on the basis of such 'national origin' - asylum seekers and undocumented migrants might equally fall within the scope of this prohibited ground. The term 'national origin' seems to be even more inclusive than 'nationality' and one could see nationality as only one part of national origin. It is therefore unclear why CESCR GC 20 mentions 'nationality' again as a separate ground under the 'other status' criterion.

While one can only speculate on the question of why the CESCR chose this arguably problematic - classification of 'nationality' within the scope of the 'other status' ground, it is important to note the CESCR's view of what this criterion should comprise. In its reference to nationality as a prohibited ground of discrimination, CESCR GC 20 explicitly refers to undocumented migrant children. As such, 'all children within a state, including those with an undocumented status, have a right to ... affordable health care. ${ }^{62}$ Again, no explicit reference to preventive health care is made and the term 'affordable health care' is left undefined. Still, it seems a bold move by the CESCR to explicitly

\footnotetext{
CESCR GC 20, supra nt 3, paras 15 and 27.

$I d$, para 27.

Ibid.

$I d$, para 30.

$I d$, paras 34 and 35.

$I d$, para 30 .

$I d$, para 24 .

Id, para 30.
} 
mention undocumented migrant children while not specifically acknowledging all other children who could find themselves in a similarly vulnerable situation due to their nationality. This seems to exhibit the CESCR's conviction that these children deserve particular attention and that hitherto this has been insufficiently acknowledged.

Apart from the overlap of 'nationality' with the 'national origin' ground, one might also ask whether the approach of including undocumented children under nationalityrelated discrimination is legally sound: asylum seekers and undocumented migrants are usually not limited in their access to economic, social and cultural rights because of their nationality or because of the fact that they originate from a particular country. Rather, States sometimes limit the access to these rights because the person requesting access has no (permanent) legal status in the host country: regardless of their country of origin, differential treatment is usually applied equally to persons from, for instance, Pakistan, China or Venezuela if they have no residence permit. ${ }^{63}$ Thus, such an exclusion from the enjoyment of ICESCR rights constitutes discrimination on the basis of legal or residence status rather than discrimination on the basis of nationality. An additional problem is posed by the fact that asylum seekers are not mentioned under the 'nationality' ground and that it is unclear whether the reference to undocumented children suggests that undocumented migrants should have the same rights or whether undocumented migrant children enjoy more rights than their parents (and if so, on what basis?).

Whereas this nevertheless generally suggests that the principle of non-discrimination at least partially also applies to non-nationals, CESCR GC 20 entails another problematic provision that suggests the opposite and protects State interests rather than individual rights. As such, CESCR GC 20 holds that discrimination is not to be seen as discrimination if the purpose of this discrimination is 'promoting the general welfare in a democratic society'. ${ }^{64}$ This seems to almost nullify the previously outlined inclusive protection against discrimination. 'General welfare' seems to be a broad concept that allows for far-reaching interpretations. ${ }^{65}$ Even arguments for only providing emergency care to undocumented persons or asylum seekers in order to not irrevocably strain the national health care system seem to lend themselves to legitimation under this provision as a functioning health care system is generally seen to be promoting the general welfare. ${ }^{66}$ While the provision further limits the justification of any such discrimination as having to be 'reasonable and objective', its 'aim and effects' having to be 'legitimate, compatible with the nature of the Covenant rights' and having 'a clear and reasonable relationship of proportionality', this nevertheless seems a serious limitation of one of the core provisions of international human rights law. ${ }^{67}$ Simultaneously, the effective implementation of the right to health requires that the discrimination has to be 'compatible with the nature of the Covenant rights'. Thus, in order to assess whether any distinctive application of the right to health would ever be compatible with this 'general welfare' provision, it is necessary to further elaborate upon the non-discrimination provision entailed in the right to health itself.

Regarding the provisions on non-discrimination entailed in the right to health itself, it has been noted above that Article 12 ICESCR holds that 'everyone' has the right to

63 Obviously, once they do have a residence permit and are still discriminated against, the situation becomes different and would most probably fall within the scope of 'nationality' or 'national origin'.

$64 \quad I d$, para 13.

65 States repeatedly assert that they cannot or do not want to award non-nationals similar rights as nationals: OHCHR, supra nt 19, 19.

66 Ibid.

67 CESCR GC 20, supra nt 3, para 13. 
health but does not entail any explicit prohibition of discrimination in the article itself. However, CESCR GC 14 on the right to health similarly holds that '[e]very human being is entitled to the enjoyment of the highest attainable standard of health' ${ }^{68}$ and additionally explicitly states that this right is 'closely related to and dependent upon' the principle of non-discrimination. ${ }^{69}$

What exactly this should entail for the right to health becomes clear in the CESCR GC 14 provisions related to non-discrimination in which frequent reference to 'health facilities, goods and services' is made. ${ }^{70}$ While this is a valuable starting point, the broadness of this phrase might lead to uncertainty about which health facilities are actually contained in this definition. This is especially problematic with regard to preventive health care. However, a footnote in CESCR GC 14 states that unless indicated otherwise, the term 'health facilities, goods and services' should be considered to include the 'underlying determinants of health'. ${ }^{71}$ CESCR GC 14 offers additional guidance through stating that the right to health 'proscribes any discrimination in access to health care and underlying determinants of health'. ${ }^{72}$ Keeping in mind the previously mentioned link between preventive health care and the underlying determinants of health, it is therefore important to note that the 'underlying determinants of health' are explicitly mentioned here.

In addition, CESCR GC 14 not only refers to non-discrimination but also to 'equality of opportunity for people to enjoy the highest attainable level of health', which seems to go beyond the primarily negative obligation of States to refrain from discriminatory treatment and implies a positive obligation for states to ensure equality. ${ }^{73}$ Moreover, the examples of violations mentioned in CESCR GC 14 clearly show that national nondiscriminatory laws alone are not enough but that the State has to actively prevent discrimination as the 'denial of access to health facilities, goods and services to particular individuals or groups as a result of de jure or de facto discrimination' is considered a violation of the right to health. ${ }^{74}$ Based on this argument, the abovementioned limitation of the non-discrimination principle of CESCR GC 20 in the interest of 'general welfare' would not be legitimate under the right to health and therefore not 'compatible with Convention rights' if it limits the access to 'health facilities, goods and services' in any way.

CESCR GC 14 even explicitly asserts that States are not allowed to deny or limit the 'equal access for all persons, including ... asylum seekers and illegal immigrants to preventive, curative and palliative health services'. ${ }^{75}$ This shows that the CESCR clearly considers asylum seekers and undocumented migrants to fall within the scope of the principle of non-discrimination and that this holds true for the whole spectrum of health, including preventive health care. Consequently, asylum seekers and undocumented migrants should be entitled to the same rights as all other subjects of human rights law and hence to all the preventive health care measures identified above.

This is confirmed by CESCR GC 14's core obligation for States ' $[t]$ o ensure the right of access to health facilities, goods and services on a non-discriminatory basis, especially for

\footnotetext{
CESCR GC 14, supra nt 3, para 1.

Id, para 3 .

See, for instance, CESCR GC 14, supra nt 3, paras 12(b), 43(a) and 50.

Id, footnote 6 .

$I d$, para 18 .

Id, para 8.

$I d$, para 50 .

$I d$, para 34.
} 
vulnerable and marginalized groups' ${ }^{76}$ Moreover, CESCR GC 14 holds that health care must be 'accessible to everyone without discrimination, within the jurisdiction of the State party' and 'to all, especially the most vulnerable and marginalized sections of the population'. ${ }^{77}$ While no specific 'sections of the population' are mentioned, one can easily assume that asylum seekers and undocumented migrants would fall within this definition. The reference to 'within the jurisdiction of the State party' seems to further define the term 'everyone' and leads to the assumption that no distinction in relation to the right to health should be made on the basis of residence status. Rather, based on these criteria, everyone present in the territory of a State that has signed and ratified the ICESCR would then be entitled to the same rights as nationals of that State. Furthermore, it is not difficult to argue that asylum seekers and undocumented migrants are usually in a vulnerable and marginalized situation that would result in them falling within the scope of this provision. However, in a different paragraph, the CESCR refers to the entitlements of 'the vulnerable members of society', which leads to the question of whether someone without a (permanent) residence permit could be considered a 'member of society'. ${ }^{78}$ In order to clarify how these and related terms are to be interpreted, it would be necessary for future research to further engage with the concept of vulnerability.

Overall, based on the ICESCR and CESCR GC 14 and 20, one can conclude that asylum seekers and undocumented migrants should enjoy the same health rights as 'everyone'. Yet, the references to asylum seekers and/or undocumented migrants are inconsistent, which makes it difficult to see whether asylum seekers and undocumented migrants should be placed on an equal footing or whether one of the two groups has more rights than the other: sometimes the CESCR refers to asylum seekers and sometimes to undocumented migrants, but this is not always done simultaneously or in the same way.

The previous analysis suggests that the possibility of derogation on the grounds of 'general welfare' in the non-discrimination principle is problematic because it can easily be employed to justify the differential treatment of asylum seekers and undocumented migrants. However, if one takes a close look at the connection of the right to health and non-discrimination, it becomes apparent that it should be considered contrary to the right to health to limit access to health care in any way. This was even found to be true with regard to preventive health care.

\section{Conclusion}

The present study tried to answer the question of what the principle of nondiscrimination has to offer for the preventive health care of asylum seekers and undocumented migrants. In so doing, it referred to two subquestions. First, what individual rights and State obligations are involved in the right to preventive health care? Second, does the principle of non-discrimination offer (additional) protection to asylum seekers and undocumented migrants in terms of the right to preventive health care? Through a doctrinal analysis which not only tried to point at inconsistencies but also

\footnotetext{
Id, para 43(a).

Id, para $12(\mathrm{~b})$.

$I d$, para 18.
} 
elaborate upon how the law should be understood according to the CESCR's General Comments, the following conclusions could be drawn.

While there is a legal basis for the right to preventive health care in Article 12 ICESCR, there is, strictly speaking, no such right for asylum seekers or undocumented migrants explicitly mentioned in the ICESCR itself. Nevertheless, implications for such a right can be found in the non-binding but authoritative CESCR GC 14 and 20. It is therefore beyond question that if one were to take due account of how the law should be interpreted according to CESCR GC 14, then there should be recognition of a right to preventive health care. State compliance with such a right should at least entail immunisation, education and information on health and behaviour-related health concerns, regular screening programmes and the promotion of the social determinants of health. However, any more extensive or more detailed content of the right to preventive health care is left undefined and should be laid down in an additional international document that explicitly deals with the right to preventive health care.

The principle of non-discrimination clearly applies to the right to health and should therefore implicitly also apply to preventive health care. However, the principle is not conclusive in answering whether the right to preventive health care would apply to asylum seekers and/or undocumented migrants in an equal manner as it would apply to nationals. Although, generally, the rights of asylum seekers are considered to be less controversial than those of undocumented migrants due to the temporary legal residence status of asylum seekers, reference to these groups is inconsistent. Generally, the CESCR seems to be more concerned with undocumented migrants and assumes asylum seekers are implicitly considered to enjoy at least the same rights.

Non-discrimination can contribute to clarifying the rights and obligations with regard to asylum seekers and undocumented migrants but also blurs these through allowing States to discriminate in the interest of 'general welfare'. The 'general welfare' limitation of the principle of non-discrimination does not seem to exist under the right to health and CESCR GC 14 seems to be more far-reaching and comprehensive than CESCR GC 20 in that respect. Non-discrimination in the right to health itself does not allow for such a general welfare limitation and CESCR GC 14 is much more outspoken in prohibiting any limitation of the right to health. While the 'other status' requirement of the principle of non-discrimination in CESCR GC 20 might offer some additional leeway of interpretation, it is also confusing through the double reference to 'nationality' and 'national origin'. If one sticks to the interpretation of CESCR GC 14, such a broadening of the 'other status' ground is not even necessary as under the right to health asylum seekers and undocumented migrants are explicitly included. As such, CESCR GC 14 asserts that States are not allowed to deny or limit the 'equal access for all persons, including ... asylum seekers and illegal immigrants to preventive, curative and palliative health services' ${ }^{79}$ While this is a far-reaching approach under CESCR GC 14, it would contribute to the acceptance of the existence and content as well as to the effectiveness of a non-discriminatory right to preventive health care for everyone, including asylum seekers and undocumented migrants, to not only envisage such a right under the right to health itself but to also make it more explicit under the 'umbrella right' of nondiscrimination.

For non-discrimination to be truly unambiguous with regard to the right to health of asylum seekers and undocumented migrants, it would be necessary to strike out the 'general welfare' provision of CESCR GC 20 and to clearly state that the 'other status'

CESCR GC 14, supra nt 3, para 34. 
The Principle of Non-discrimination: An Empty Promise for the Preventive Health Care of Asylum Seekers and Undocumented Migrants?

criterion also entails 'residence status' as a prohibited ground of discrimination rather than only repetitively 'nationality'. Hence, it can be concluded that it is not so much the principle of non-discrimination that has to offer protection for the preventive health care of asylum seekers and undocumented migrants, but rather the other way round: the right to health can and should offer additional clarification on the non-discrimination of asylum seekers and undocumented migrants.

*

\section{www.grojil.org}

